\title{
Clinical Manifestations of Partial Trisomy 2p
}

\author{
losif W. Lurie
}

Chromosome Disorder Outreach, Boca Raton, Fla., USA

Sir,

Martínez-Juárez et al. [2014] reported 2 siblings with trisomy $2 \mathrm{p}$ caused by maternal translocation $\mathrm{t}(2 ; 12)$ (p22.3q24.3). Neither of these siblings nor several other patients with pure trisomy $2 \mathrm{p}$ cited by these authors had congenital diaphragmatic hernia $(\mathrm{CDH})$, neuroblastoma or neural tube defects (NTD). Almost 20 years ago, we [Lurie et al., 1995] suggested that these findings are causally related to trisomy $2 \mathrm{p}$. Martínez-Juárez et al. state that our conclusion was false and that these findings actually are caused by associated chromosomal imbalances.

$\mathrm{CDH}$ was reported in 7 patients with trisomy $2 \mathrm{p}$ (table 1). Four of these patients had associated deletions for other chromosomes, 1 had mosaic trisomy for the whole $2 \mathrm{p}$ and proximal part of $2 \mathrm{q}$ (from centromere to $2 \mathrm{q} 11.2$ ) [Kan et al., 2014], and 2 had pure trisomy 2p [Heathcote et al., 1991; Blassnig-Ezeh et al., 2013]. In the latter observation, absence of any associated imbalance was confirmed by molecular methods. Blassnig-Ezeh et al. [2013] narrowed down the critical segment for $\mathrm{CDH}$ to approximately $8 \mathrm{Mb}$ (between 42.3 and $50.0 \mathrm{Mb}$ ) on 2 p21. In that context, there are no reasons to relate the origin of $\mathrm{CDH}$ to any chromosomal abnormalities that accompanied trisomy $2 \mathrm{p}$.
Table 1. $\mathrm{CDH}$ in individuals with partial trisomy $2 \mathrm{p}$

\begin{tabular}{lll}
\hline Reference & Trisomic segment & Associated imbalance \\
\hline Kan et al., 2014 & 2cen-pter (mosaic) & dup 2cen-q11.2 (mosaic) \\
Sarda et al., 1992 & 2p13pter & del Xp13pter \\
Blassnig-Ezeh et al., 2013 & 2p16.3p21 & - \\
Mosca et al., 2011 & 2p16.3pter & del 15q26.2qter \\
Heathcote et al., 1991 & 2p21p25 & - \\
León León et al., 2011 & 2p21pter & del 18p11pter \\
Bender et al., 1969 & 2p23pter & del 6p25pter \\
\hline
\end{tabular}

Table 2. Neuroblastoma in individuals with partial trisomy $2 p$

\begin{tabular}{lll}
\hline Reference & Trisomic segment & Associated imbalance \\
\hline Say et al., 1980 & 2p21p25 & - \\
Dowa et al., 2006 & 2p21pter & del 8p23.2pter \\
Stephane et al., 2003 & 2p22pter & del 8p23pter \\
Nagano et al., 1980 & 2p22.3pter & del 16p13.3pter \\
Patel et al., 1997 & 2p23pter & del 13q34qter \\
Yüksel et al., 2002 & 2p23pter & del 17q25qter \\
Morgenstern et al., 2014 & 2p23pter & del 16p13.3pter \\
Nowaczyk et al., 2000 & 2p23.2pter & del 7q36.1qter \\
Warad et al., 2012 & 2p24.1p25.3 & - \\
Lipska et al., 2013 & 2p24.1pter & del 18q22.3qter \\
Van Mater et al., 2013 & 2p24.3 (1 Mb) & dup 3q29 $(0.144 \mathrm{Mb})$ \\
& & del 20p12.1 $(0.219 \mathrm{Mb})$ \\
\hline
\end{tabular}

Iosif W. Lurie

913 Rachel Jordan Court Owings Mills, MD 21117 (USA)

E-Mail iosifw@gmail.com 
Table 3. NTD in individuals with partial trisomy $2 p$

\begin{tabular}{llll}
\hline Reference & Trisomic segment & Associated imbalance & Type of defect \\
\hline Therkelsen et al., 1973 & 2p13p24 & - & spina bifida \\
Fineman et al., 1983 & 2p13pter & del 9p24pter & spina bifida \\
Walbaum et al., 1984 & 2p13pter & del 5p15pter & anencephaly \\
Sarda et al., 1992 & 2p13pter & del Xp13pter & spina bifida \\
Mosca et al., 2011 & 2p16.3pter & del 15q26.2qter & spina bifida \\
Hahm et al., 1999 & 2p21pter & del 15q26qter & anencephaly, spina bifida \\
Kim et al., 2007 & 2p21pter & del 5p15pter & exencephaly \\
Thangavelu et al., 2004, case 1 & 2p22p25 & - & anencephaly \\
Thangavelu et al., 2004, case 2 & 2p22p25.3 & - & anencephaly \\
Doray et al., 2003, case 1 & 2p22pter & del 15q26qter & anencephaly, spina bifida \\
Doray et al., 2003, case 2 & 2p22pter & del 15q26qter & anencephaly \\
Winsor et al., 1997, case 1 & 2p23pter & del 5p15pter & anencephaly \\
Winsor et al., 1997, case 2 & 2p23pter & del 5p15pter & anencephaly \\
Stallworth et al., 2008 & 2p23pter & del 9p24pter & anencephaly, spina bifida \\
Wellesley and Boyle, 2000 & 2p23.1pter & del 3q29qter & anencephaly, spina bifida \\
Singer et al., 1987 & 2p24pter & del 10q26qter & anencephaly \\
Cain et al., 2008 & 2p25.1pter & del 13q32qter & occipital encephalocele \\
Gregory et al., 2000, case 1 & 2p25.2pter & del 10q26.3qter & anencephaly \\
Gregory et al., 2000, case 2 & 2p25.2pter & del 10q26.3qter & anencephaly \\
Poulose et al., 2007 & 2p25.2pter & del 10q26.3qter & 'exencephaly-anencephaly' \\
\hline
\end{tabular}

At least 11 patients with trisomy $2 \mathrm{p}$ developed neuroblastoma (table 2). Two of these patients had pure trisomy 2p [Say et al., 1980; Warad et al., 2012], another had an additional 0.144-Mb duplication of 3q29 and a 0.219$\mathrm{Mb}$ deletion of 20p12.1 [Van Mater et al., 2013]. In the opinion of Martínez-Juárez et al. [2014], a person with an imbalance of this size may be classified as pure duplication 2p. Eight others had an associated imbalance. New data show that duplication of the MYCN locus at 2p24.3 is responsible for the origin of neuroblastoma in patients with trisomy 2p [Lipska et al., 2013].

NTD were found in 20 published patients with trisomy $2 p$ (table 3). There are no other partial trisomies where NTD were reported in such a large number of persons. In at least 3 patients [Therkelsen et al., 1973; Thangavelu et al., 2004], anencephaly or spina bifida was found without any associated imbalance.

Of course, several reports of the above-mentioned abnormalities in individuals with pure trisomy $2 p$ were published in the 'pre-molecular era', and a tiny associated imbalance for other chromosomal segments could not be completely excluded. However, neither of the partial monosomies associated with neuroblastoma (deletions of the distal parts of 7q, 8p, 13q, 16p, 17q, or 18q) are known as causative factors for the origin or this tumor. The same is true for partial monosomies in patients with trisomy $2 p$ and NTD, because these deletions (with the exception of del 13q) are not known as being associated with anencephaly or spina bifida. These facts suggest that trisomy $2 p$ itself but not the associated imbalances are responsible for the origin of NTD.

So, there is strong evidence that all 3 groups of the above-mentioned defects are caused by trisomy $2 \mathrm{p}$, but not by the associated imbalance.

Martínez-Juárez et al. [2014] state that a horseshoe kidney observed in one of their patients is a 'previously unrecognized defect associated with this syndrome'. Actually, however, horseshoe kidney was reported both in patients with pure trisomy $2 p$ [Cummings et al., 1997] and in association with another imbalance [Larson et al., 1982].

Also, both siblings reported by Martínez-Juárez et al. [2014] were presented by Quintana Palma et al. [2010] at the 35th annual meeting of the Mexican Society of $\mathrm{Hu}-$ man Genetics. The published abstract of their presentation states that the boy had unilateral renal agenesis and hypospadias (although in the article they describe these defects as horseshoe kidney and overriding scrotum).

Precise description of the phenotype, thorough and critical review of the literature, as well as care in drawn conclusions are important issues to consider in the writing of any scientific paper. 


\section{References}

Bender K, Reinwein H, Gorman LZ, Wolf U: Familiäre 2/C-Translokation: 46,XY,t (2p-;Cp+) und 46,XX,Cp+. Humangenetik 8:94-104 (1969).

-Blassnig-Ezeh A, Bandelier C, Frühmesser A, Revencu N, Krabichler B, et al: Severe growth retardation, delayed bone age, and facial dysmorphism in two patients with microduplications in $2 \mathrm{p} 16 \rightarrow \mathrm{p} 22$. Am J Med Genet A 161A:3176-3181 (2013)

-Cain CC, Saul DO, Oehler E, Blakemore K, Stetten G: Prenatal detection of a subtle unbalanced chromosome rearrangement by karyotyping, FISH and array comparative genomic hybridization. Fetal Diagn Ther 24:286-290 (2008).

Cummings JH, Surti U, Mowery-Rushton P, Bay CA: Mosaic partial trisomy 2p: completion of chromosomal characterization 17 years after initial visit. Am J Hum Genet 61, Suppl:A372 (1997).

Doray B, Favre R, Gasser B, Girard-Lemaire F, Schluth C, Flori E: Recurrent neural tube defects associated with partial trisomy $2 \mathrm{p} 22$ pter: report of two siblings and review of the literature. Genet Couns 14:165-172 (2003).

Dowa Y, Yamamoto T, Abe Y, Kobayashi M, Hoshino R, et al: Congenital neuroblastoma in a patient with partial trisomy of $2 \mathrm{p}$. J Pediatr Hematol Oncol 28:379-382 (2006).

Fineman RM, Buyse M, Morgan M: Variable phenotype associated with duplication of different regions of 2p. Am J Med Genet 15:451456 (1983).

Gregory L, Davis T, Bonney J, Delmege D, Skirton $\mathrm{H}$, Lunt P: Trisomy for the region $2 \mathrm{p} 25.2$ to 2 pter with a variable phenotype. J Med Genet 37, Suppl 1:S52 (2000).

-Hahm GK, Barth RF, Schauer GM, Reiss R, Opitz JM: Trisomy 2 p syndrome: a fetus with anencephaly and postaxial polydactyly. Am J Med Genet 87:45-48 (1999).

-Heathcote JG, Sholdice J, Walton JC, Willis NR, Sergovich FR: Anterior segment mesenchymal dysgenesis associated with partial duplication of the short arm of chromosome 2. Can J Ophthalmol 26:35-43 (1991).

- Kan ASY, Lau ET, Tang WF, Chan SSY, Ding SCK, et al: Whole-genome array CGH evaluation for replacing prenatal karyotyping in Hong Kong. PLoS One 9:e87988 (2014).

Kim SJ, Kim MJ, Kim MS, Park IY, Hur SY, et al: Prenatal 3D-ultrasound diagnosis of exencephaly associated with partial trisomy $2 \mathrm{p}$ and distal $5 p$ deletion. Acta Obstetr Gynaecol Japon 59:775, abstract P1-IS-53 (2007).

Larson LM, Wasdahl WA, Saumur JH, Coleman ML, Hall JG, et al: Familial reciprocal translocation, $\mathrm{t}(2 ; 10)(\mathrm{p} 24 ; \mathrm{q} 26)$, resulting in duplication $2 \mathrm{p}$ and deletion 10q. Clin Genet 21:187195 (1982).
León León C, Velázquez Wong AC, Rodríguez Palacios ME, Huicochea Montiel JC, Cárdenas Conejo A, et al: Trisomía parcial de $2 \mathrm{p}$ y monosomía parcial de $18 \mathrm{p}$ con presencia de dysplasia septoóptica. Asociation Mexicana de Genetica Humana, XXXVI Congresso, Abstract CG6 (2011).

Lipska BS, Koczkowska M, Wierzba J, Ploszynska A, Iliszko $\mathrm{M}$, et al: On the significance of germline cytogenetic rearrangements at MYCN locus in neuroblastoma. Mol Cytogenet 6:43 (2013).

Lurie IW, Ilyina HG, Gurevich DB, Rumyantseva NV, Naumchik IV, et al: Trisomy 2p: analysis of unusual phenotypic findings. Am J Med Genet 55:229-236 (1995).

Martínez-Juárez A, Uribe-Figueroa L, QuintanaPalma M, Razo-Aguilera G, Sevilla-Montoya R: Pure trisomy 2 p syndrome in two siblings with an unbalanced translocation and minimal terminal $12 \mathrm{q}$ monosomy characterized by high-density microarray. Cytogenet Genome Res 142:249-254 (2014).

Morgenstern DA, Soh SY, Stavropoulos DJ, Bowdin S, Baruchel S, et al: Metachronous neuroblastoma in an infant with germline translocation resulting in partial trisomy $2 \mathrm{p}$ : a role for ALK? J Pediatr Hematol Oncol 36:e193-e196 (2014).

Mosca AL, Pinson L, Andrieux J, Copin H, Bigi N, et al: Refining the critical region for congenital diaphragmatic hernia on chromosome $15 q 26$ from the study of four fetuses. Prenat Diagn 31:912-914 (2011).

Nagano H, Kano Y, Kobuchi S, Kajitani T: A case of partial 2 p trisomy with neuroblastoma. Jpn J Hum Genet 25:39-45 (1980).

Nowaczyk MJM, Huggins MJ, Tomkins DJ, Rossi E, Woulfe J, et al: Holoprosencephaly, sacral anomalies, and situs ambiguous in an infant with partial monosomy $7 \mathrm{q} /$ trisomy $2 \mathrm{p}$ and SHH and HLXB9 haploinsufficiency. Clin Genet 57:388-393 (2000).

Patel JS, Pearson J, Willatt L, Andrews T, Beach R, Green A: Germline duplication of chromosome $2 \mathrm{p}$ and neuroblastoma. J Med Genet 34: 949-951 (1997).

Poulose T, Tsepov D, Fox R: Familial exencephaly-anencephaly sequence and translocation. J Obstet Gynaecol 27:317-318 (2007).

Quintana Palma M, Martínez-Juárez A, Razo Aguilera G, Grether González P, Nieto Martínez $\mathrm{K}$, et al: Características fenotípicas en una pareja de hermanos con trisomía parcial 2 p y monosomía parcial $12 \mathrm{q}$ resultants de una translocación maternal balanceada 2; 12(p22.2;q24.31). Asociation Mexicana de Genetica Humana, XXXV Congresso, Abstract (2010).
Sarda P, Lefort G, Devaux P, Huneau C, Rieu D: Multiple congenital anomalies due to partial 2 p13 $\rightarrow 2$ pter duplication resulting from an unbalanced X;2 translocation. Ann Genet 35: 117-120 (1992).

Say B, Carpenter NJ, Giacoia G, Jegathesan S: Agenesis of the lung associated with a chromosomal abnormality $(46, \mathrm{XX}, 2 \mathrm{p}+)$. J Med Genet 17:477-478 (1980).

Singer N, Gersen S, Warburton D: The value of chromosome analysis in cases of neural tube defects: a case of anencephaly associated with fetal dup (2)(p24 $\rightarrow$ pter). Prenat Diagn 7:567571 (1987)

Stallworth JL, Avert JM, DuPont BR, Lebel RR: Partial trisomy $2 \mathrm{p}$ and partial monosomy $9 \mathrm{p}$ in a fetus with anencephaly, polydactyly, and other abnormalities. Proc Greenwood Genet Center 27:18-21 (2008).

Stephane R, Genevieve D, Sanlaville D, Maltret A, Serrero S, et al: Trisomy $2 \mathrm{p}$ and monosomy $8 \mathrm{p}$ in a patient with DiGeorge syndrome. Am J Hum Genet 75, Suppl:266 (2003).

Thangavelu M, Frolich G, Rogers D: Partial duplication $2 \mathrm{p}$ as the sole abnormality in two cases with anencephaly. Am J Med Genet A 124A: 170-172 (2004).

Therkelsen AJ, Hultén M, Jonasson J, Lindsten J, Christensen NC, Iversen T: Presumptive direct insertion within chromosome 2 in man. Ann Hum Genet 36:367-373 (1973).

Van Mater D, Knelson EH, Kaiser-Rogers KA, Armstrong MB: Neuroblastoma in a pediatric patient with a microduplication of $2 \mathrm{p}$ involving the MYCN locus. Am J Med Genet A 161A:605-610 (2013).

Walbaum R, Peyrat MF, van de Velde MF, Guerin du Masgenet B, Bethouart M, Farriaux JP: Fail-il caryotyper les parents d'enfants atteints d'anomalies de fermeture du tube neural? J Genet Hum 32:307 (1984).

Warad D, Kirmani S, Marri Reddy P, Nemergut M, Rodriguez V, Nageswara Rao A: Perinatal neuroblastoma with a germline interstitial $2 \mathrm{p}$ duplication involving the $M Y C N$ gene: a case report. Arch Dis Child 97 (Suppl 2):A161A162 (2012).

Wellesley D, Boyle T: Regarding trisomy 2p syndrome. Am J Med Genet 92:295 (2000).

-Winsor SH, McGrath MJ, Khalifa M, Duncan AM: A report of recurrent anencephaly with trisomy 2p23-2pter: additional evidence for the involvement of 2 p24 in neural tube development and evaluation of the role for cytogenetic analysis. Prenat Diagn 17:665-669 (1997).

Yüksel A, Seven M, Karaman B, Yilmaz S, Deviren A, et al: Neuroblastoma in a dysmorphic girl with a partial duplication of $2 p$ caused by an unbalanced translocation. Clin Dysmorphol 11:39-42 (2002). 